\title{
PRESS-FIT EVALUATION AND STUDY OF DISPLACEMENT IN TEMPERATURE CHANGES
}

\author{
$\breve{S ̆ L E S A R ~ P e t e r ~}^{1}$, JANČO Roland ${ }^{2}$ \\ ${ }^{1}$ Slovak University of Technology in Bratislava, Faculty of Mechanical Engineering, Institute of Applied \\ Mechanics and Mechatronics, Nám. Slobody 17,812 31 Bratislava, Slovakia, email: peter.slesar@stuba.sk \\ ${ }^{2}$ Slovak University of Technology in Bratislava, Faculty of Mechanical Engineering, Institute of Applied \\ Mechanics and Mechatronics, Nám. Slobody 17,812 31 Bratislava, Slovakia, email: roland.janco@stuba.sk
}

\begin{abstract}
The article is devoted to bearing analysis, which has a specific shape. The outer ring is the body directly and the inner ring is the case. To determine optimal radial clearance or overlap are used the thermal / structural analysis. The article is logically divided into two parts. In the first analysis, was monitored the impact of the press-fit of the case into the body. In the second analysis, there are presented attained results in graphical outputs of displacements in the orbits at different operating temperatures. At the end of the article were evaluated and researched individual effects on bearing deformation.
\end{abstract}

KEYWORDS: radial displacements of ball and roller raceways, thermal analysis, structural analysis, bearing, basic reference rating life

\section{Introduction}

Purpose of the presented press-fit calculation was the investigation of displacements behavior of outer ring raceways at temperatures $+20^{\circ} \mathrm{C},-30^{\circ} \mathrm{C}$ and $+120^{\circ} \mathrm{C}$. Housing was a body with non-constant radial stiffness because of ribbed shape. Therefore this study has to support design of radial clearance and describe influence of its displacements after press-fit at each temperature load $[1,4,5,6,7,8]$. For calculation of thermal displacement of other components in the bearing: balls, rollers, shaft; there is used analytical method based on linear thermal expansion theory for symmetric bodies. FEA Calculation was provided using software MSC Marc with following models. Bore-diameter of housing and outer ring diameter represents the critical interference: minimum diameter of bore and maximum diameter of outer ring. The dimensions of the outer and inner rings are shown in Table 1.

Table 1: Diameter outer and inner rings

\begin{tabular}{|c|c|}
\hline Name & Diameter $(\mathrm{mm})$ \\
\hline \hline Outer ring $(\mathrm{Or})$ & 30,000 \\
\hline Inner ring $(\mathrm{Ir})$ & 29,927 \\
\hline
\end{tabular}
(1).[2]

Overhang (Pr) of the bearing before press-fit was calculated according to the equation

$$
\operatorname{Pr}=\frac{\frac{\text { or }}{2 r}}{2}=\frac{\frac{30,000}{29,927}}{2}=0,0365 \mathrm{~mm}
$$

where $\mathrm{Or}$ is diameter outer ring and $\mathrm{Ir}$ is diameter inner ring 


\section{$2 \quad$ Model for thermal / structural analysis}

Analysis model in the Fig. 1 was modified due to eliminate unnecessary details and was set up in FEA environment. Housing was meshed by using approx. 110000 of 3D elements type: TETRA 4 (4 nodes tetrahedron). Outer ring of bearing was meshed by using approx. 42000 of 3D elements type: HEX 8 (8 nodes hexahedron) [3]. Boundary conditions are following: Housing was fixed and outer ring of bearing has defined displacement to press-fit outer ring into final position. Analysis was carried out by using implicit solver.

Press-fit was performed at initial temperature $20^{\circ} \mathrm{C}$. After press-fit was applied thermal load steps. Subsequently decrease of temperature at minimum $-30^{\circ} \mathrm{C}$ and increase at maximum temperature $120^{\circ} \mathrm{C}$. In each load step was recorded radial thermal-structural displacement.

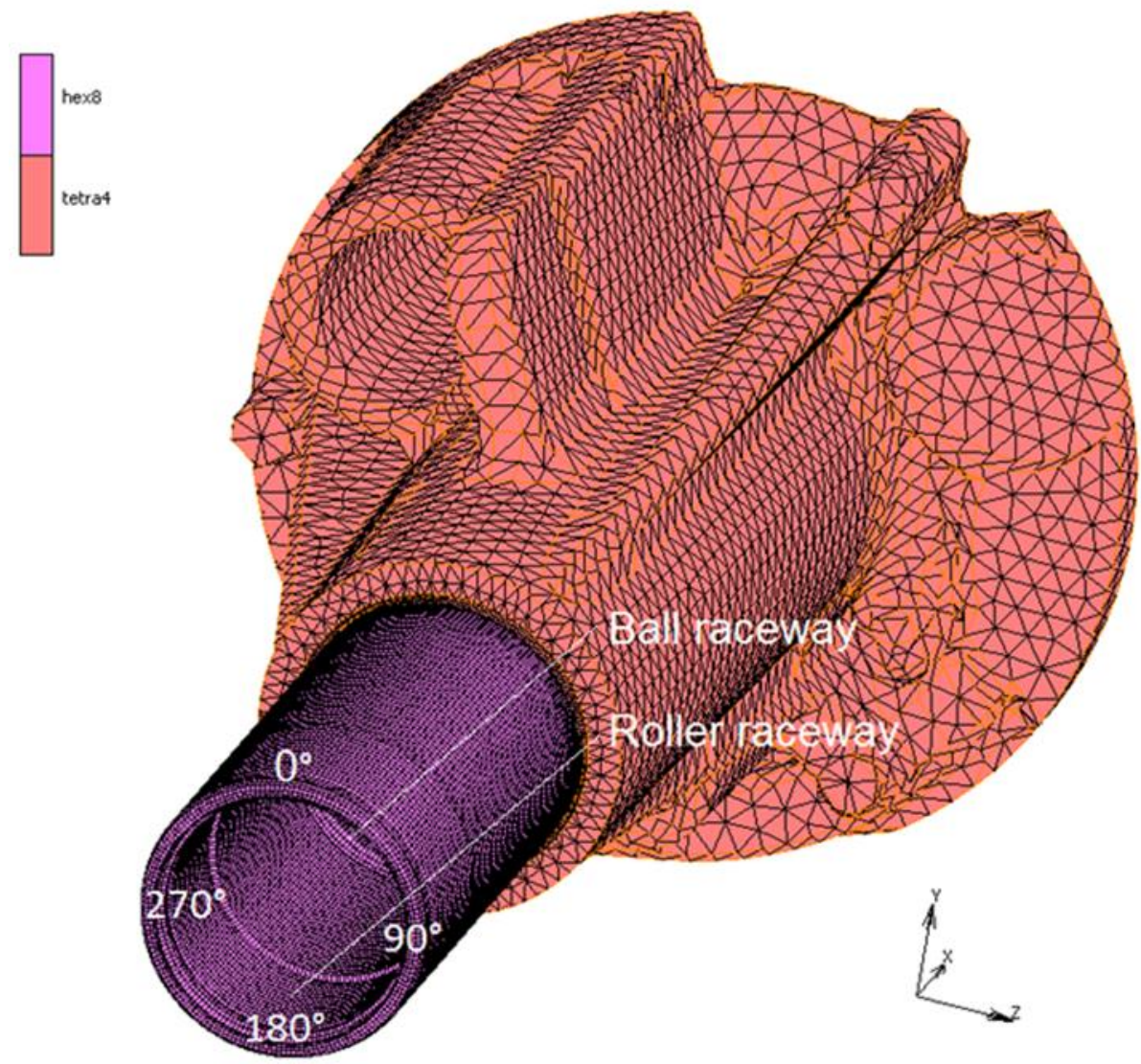

Fig. 1 Model for thermal / structural analysis.

\section{$3 \quad$ Material model}

For the calculation of aluminum part was used bilinear material model of A1Si9Cu with the Young's modulus $\mathrm{E}=69.000 \mathrm{~N} / \mathrm{mm}^{2}$, yield strength $\mathrm{R}_{\mathrm{e}}=140 \mathrm{MPa}$, Ultimate strength $\mathrm{R}_{\mathrm{m}}=240 \mathrm{MPa}$, Elongation $\mathrm{A}_{50 \mathrm{~mm}}=1 \%$, Poisson's ratio $\mu=0.3$ and linear thermal expansion coefficient $\alpha=21 \times 10^{-6} \circ \mathrm{K}$. [3] 


\section{$4 \quad$ Results from numerical solution}

From the Fig. 2 is obvious that there were positive displacement at aluminum body and negative displacement at outer ring of the bearing. Radial displacement or deformation of ball and roller raceways were exported into the polar graphs shown in Fig. 3 and Fig. 4. Red curve correlate with local radial stiffness of the body.

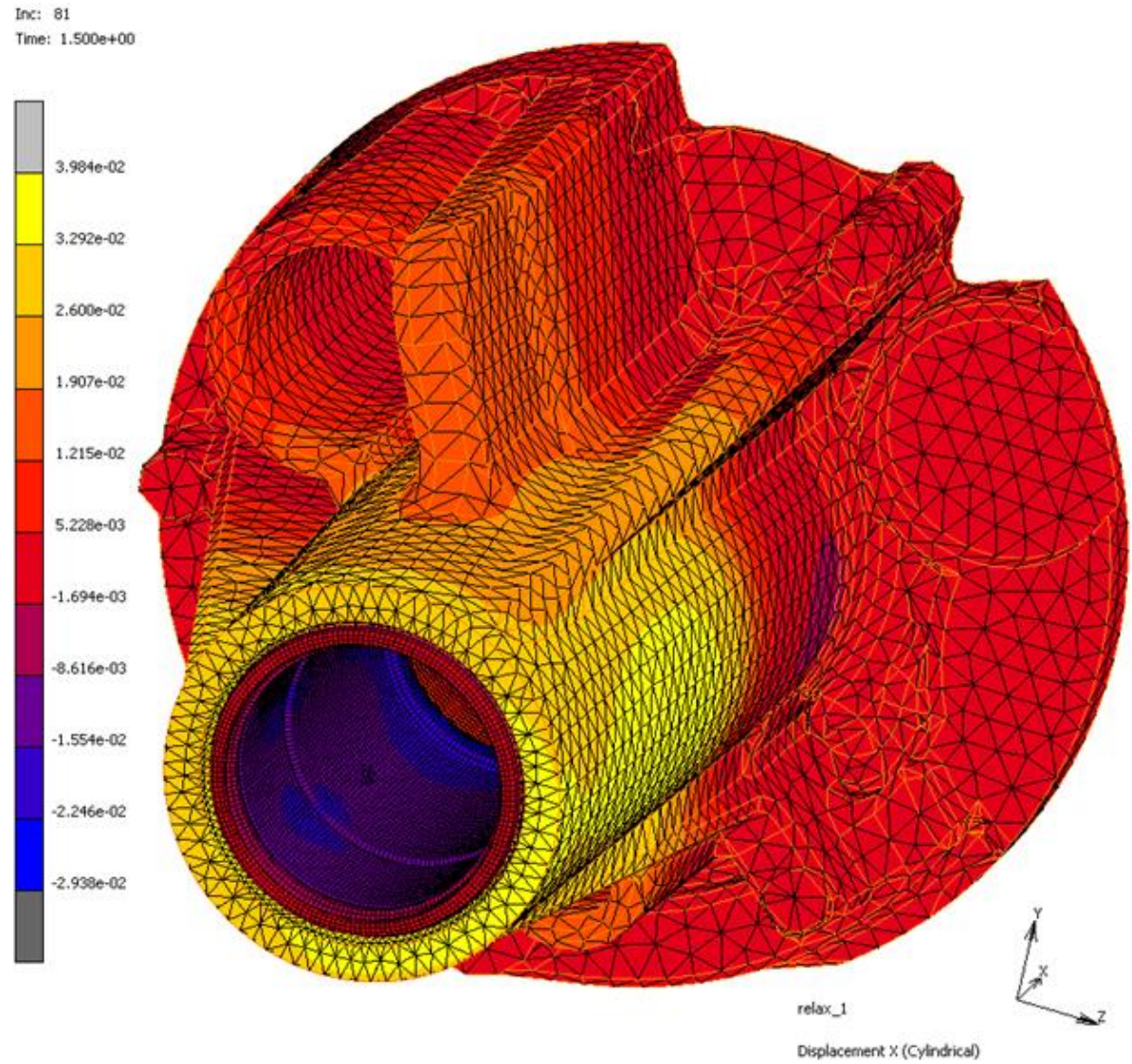

Fig. 2 Radial displacement at $20^{\circ} \mathrm{C}$.

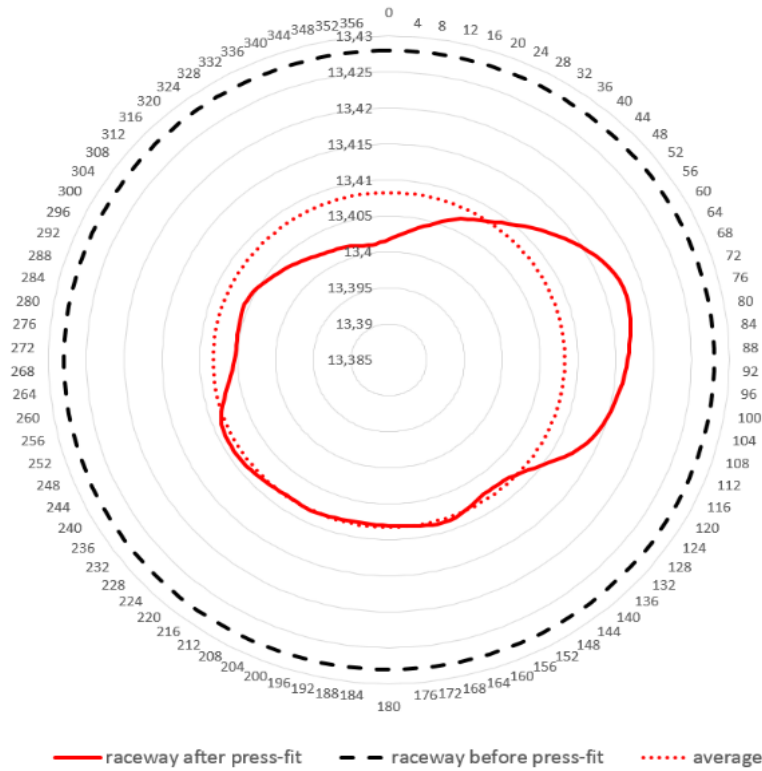

Fig. 3 Ball raceway deformation at $20^{\circ} \mathrm{C}$.

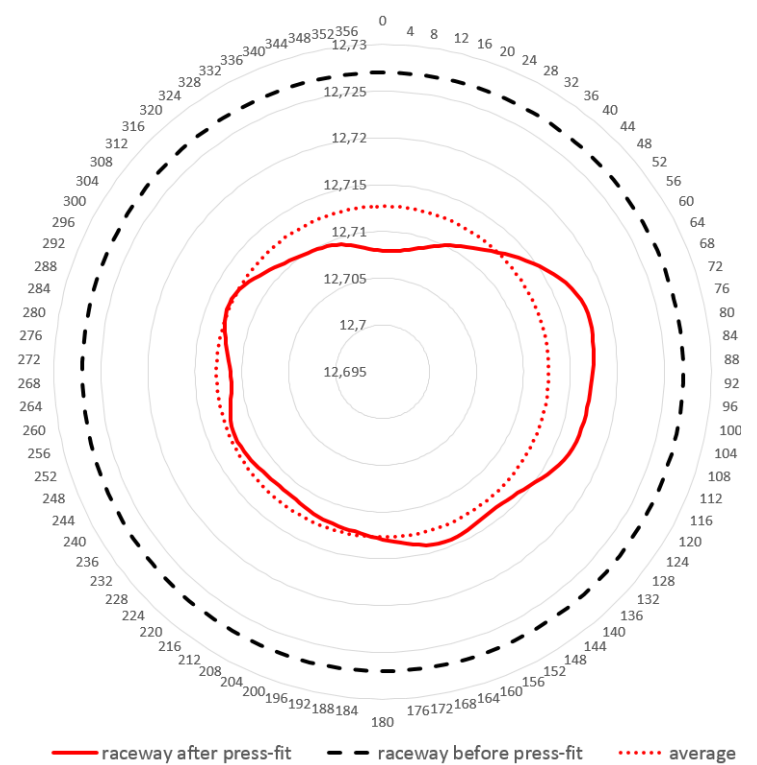

Fig. 4 Roller raceway deformation at $20^{\circ} \mathrm{C}$. 
These issues were obtained for all the required temperatures. All results were written in Table 2 and the graphic results shown in the Figure 5.

Table 2: Design and assessment of radial clearance or overhang

\begin{tabular}{|c|c|c|c|c|c|}
\hline \multicolumn{2}{|c|}{ Temperature } & $-30^{\circ} \mathrm{C}$ & $20^{\circ} \mathrm{C}$ & $90^{\circ} \mathrm{C}$ & $120^{\circ} \mathrm{C}$ \\
\hline \multicolumn{2}{|c|}{ component } & \multicolumn{4}{|c|}{ Radial deformations } \\
\hline \multicolumn{2}{|c|}{ Ball } & $-0,00371$ & 0,00000 & 0,00520 & 0,00743 \\
\hline \multicolumn{2}{|c|}{ Roller } & $-0,00278$ & 0,00000 & 0,00390 & 0,00557 \\
\hline \multicolumn{2}{|c|}{ Ball raceway of shaft } & $-0,00827$ & 0,00000 & 0,01158 & 0,01654 \\
\hline \multicolumn{2}{|c|}{ Roller raceway of shaft } & $-0,00931$ & 0,00000 & 0,01304 & 0,01862 \\
\hline \multicolumn{2}{|c|}{ Ball raceway of outer ring } & $-0,06695$ & $-0,03948$ & $-0,00456$ & 0,01036 \\
\hline \multicolumn{2}{|c|}{ Roller raceway of outer ring * } & $-0,05439$ & $-0,02860$ & 0,00230 & 0,01575 \\
\hline \multicolumn{2}{|r|}{ + Clearance } & \multicolumn{4}{|c|}{ + Clearance or overhang - } \\
\hline \multirow{2}{*}{ Ball raceway } & Min. 0,033 & $-0,01825$ & $-0,00648$ & 0,00646 & 0,01196 \\
\hline & Max. 0,048 & $-0,00525$ & 0,00852 & 0,02146 & 0,02696 \\
\hline \multirow{2}{*}{ Roller raceway } & Min. 0,033 & $-0,00651$ & 0,00440 & 0,01447 & 0,01899 \\
\hline & Max. 0,048 & 0,00849 & 0,01940 & 0,02947 & 0,03399 \\
\hline
\end{tabular}

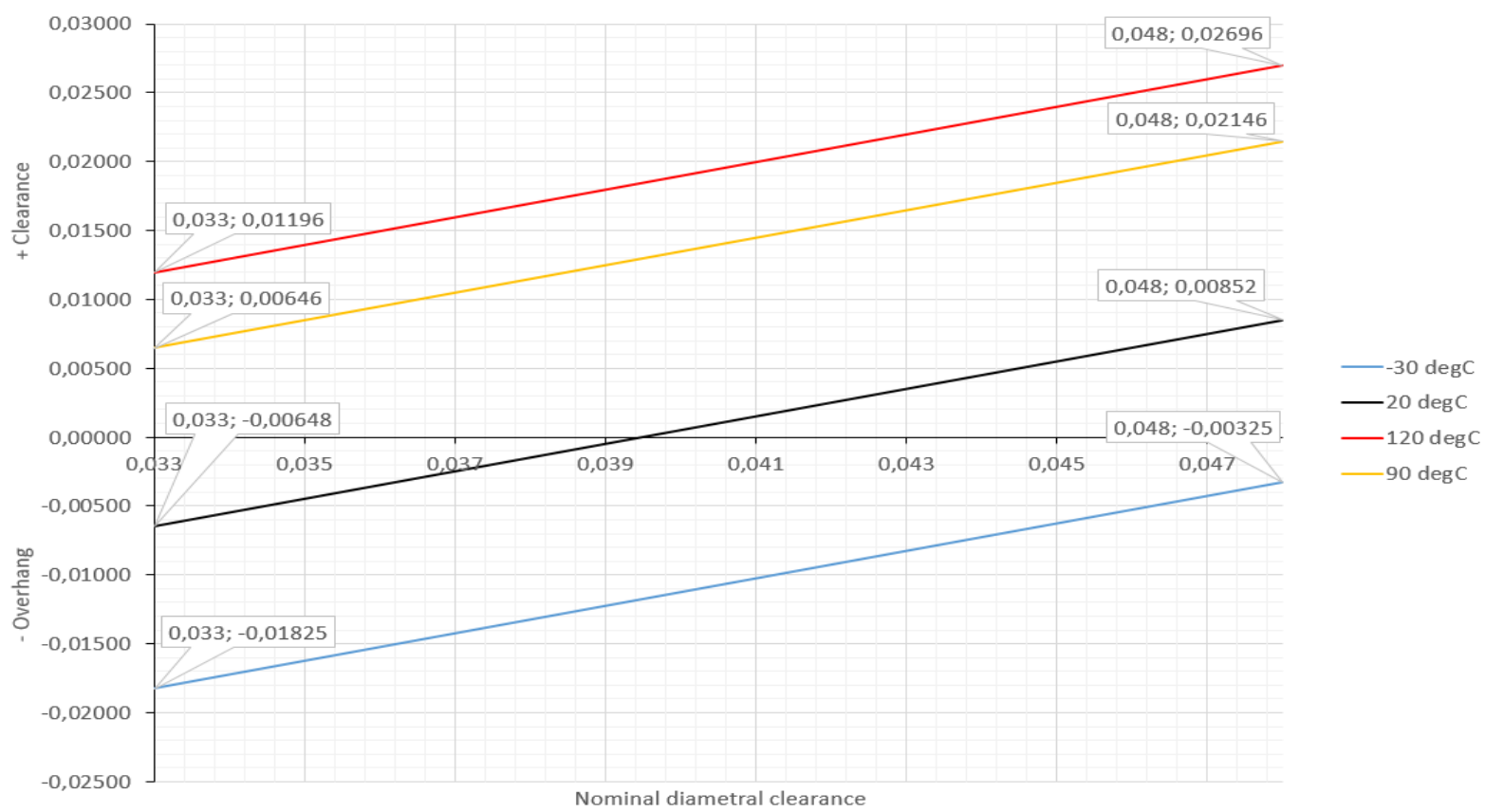

Fig. 5 Ball raceway press-fit effect on radial clearance; X-axis: Diametral clearance before press-fit; Y-axis: clearance or overhang after press-fit

In Fig. 6 was showed blue curve as a function of reference rating life according diametral clearance and overhang. From the result was obvious, that worst overhang $-0,0182$ $\mathrm{mm}$ at $-30^{\circ} \mathrm{C}$, was on the border of usability. 


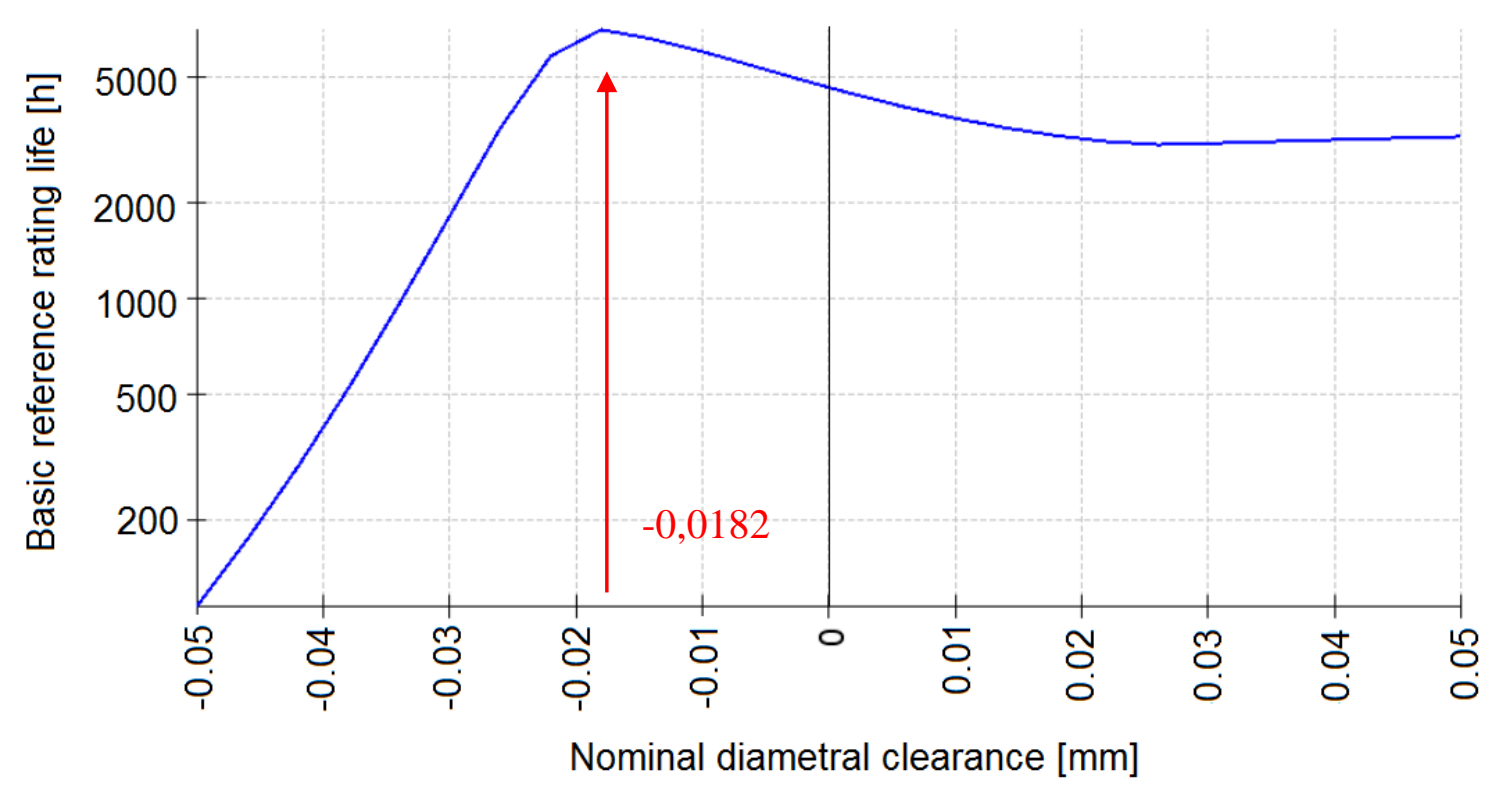

Fig. 5 Basic reference rating life of ball raceway as a function of diametral clearance or overhang

\section{CONCLUSION}

Performed FEA calculations show radial displacements of ball and roller raceways after press-fit into housing at $20^{\circ} \mathrm{C}$ and after temperature loads $-30^{\circ} \mathrm{C}$ and $+120^{\circ} \mathrm{C}$. As well as outer ring is analyzed also thermal displacement of other component of the bearing are calculated analytically.

Calculated displacements and designed radial clearance are used in equation for final evaluation of clearance or overhang after press-fit at each temperature load. Using radial play $0,033 \div 0,048 \mathrm{~mm}$ for both raceway, the optimal range for use was achieved (Fig. 5). Critical point was at $-30^{\circ} \mathrm{C}$ when ball raceway is assembled with minimal clearance $0,033 \mathrm{~mm}$ and bore of aluminium body is minimal. In terms of functionality, Fig. 6 shows, that overhang 0,0182 is on the border of usability.

\section{ACKNOWLEDGEMENTS}

The paper was supported by the grant from Grant Agency of VEGA no. 1/0740/16 entitled "Mathematical model proposal for numerical simulation of creep behavior of TiAL intermetallic alloys" and KEGA no. 017STU-4/2018 entitled "Theoretical and Practical Solution of Structures on Elastic Linear and Nonlinear Foundation". This work was supported by the Slovak Research and Development Agency under the Contract no. APVV-15-0630 entitled "Extension of the Validity of the Computation Standards for the Seismically Resistant Liquid Storage Tanks, in terms of Safety at NPPs and Other Industrial Areas".

\section{REFERENCES}

[1] Ran Zhiguo, Yan Ying, Li Jianfeng, Qi Zhongxing, Yang Lei. Determination of thermal expansion coefficients for unidirectional fiber-reinforced composites. Chinese Journal of Aeronautics 2014 (27), No. 5, 1180 - 1187. DOI: 10.1016/j.cja.2014.03.010

[2] Zdeněk Vlasák, Výpočet tolerovaných rozměrů, Oddyseus, 2004, online: http://www.zvlasak.net/vvystupy/2_3_1/vypocet_tolerovanych\%20_rozmeru.pdf

[3] MSC-MENTAL, Advanced Nonlinear Simulation Solution, MSC Software Corporation, 2015. 
[4] R. Halama, A. Markopoulos, M. Šofer, Z. Poruba, P. Matušek. Cyclic Plastic Properties of Class C Steel Emphasizing on Ratcheting Testing and Modelling. Journal of Mechanical Engineering - Strojnícky časopis 2015 (65), No. 1, pp. 21 - 26.

[5] J. Bocko, P. Lengvarský. Buckling of single-walled carbon nanotubes with and without defects, J. Mech. Sci. Technol. 2017 (4), 1825 - 1833.

[6] R. Owsinski, A. Nieslony. Identification of Fatigue Cracks on the Basisc of Measurable Changes in System Dynamics. Journal of Mechanical Engineering - Strojnícky časopis 2017 (67), No. 2, pp. 77 - 84.

[7] F. Trebuňa, F. Šimčák, Elasticity, strength and plasticity in mechanical engineering. Edition of scientific and special publications - Faculty of Mech. Eng. TU in Kosice, Emilena, Košice 2005. ISBN 80-8073-276-0.

[8] F. Trebuňa, F. Šimčák, J. Bocko, and M. Pástor, Analysis of the Causes of Casting Pedestal Failures and the Measures for Increasing Their Residual Lifetime, Engineering Failure Analysis 2013 (29), 27 - 37. 